\title{
Morphological Changes of Frankel Functional Regulator III in Mixed Dentition with Class III Malocclusion
}

\author{
Cambios Morfológicos del Regulador Funcional Frankel III \\ en Dentición Mixta con Maloclusión Clase III
}

\author{
Li-Li Ji ${ }^{1,2}$;Dan-Xu Sun ${ }^{3}$; Ling-Bo Shi ${ }^{1,2} ;$ Hee-Moon Kyung ${ }^{3}$; Li Bing ${ }^{1,2} \&$ Xiu-Ping Wu ${ }^{1,2}$
}

JI, L. L.; SUN, D. X.; SHI, L. B.; KYUNG, H. M.; BING, L. \& WU, X. P. Morphological changes of Frankel functional regulator III in mixed dentition with class III malocclusion. Int. J. Morphol., 38(4):1053-1059, 2020.

SUMMARY: The aim of this study was to evaluate the hard and soft tissue profile changes following treatment of functional and mild skeletal class III malocclusion in mixed dentition by means of the Frankel functional regulator (FR-3) appliance, and to reveal the mechanism and effectiveness of treatment with FR-3 appliance. Twenty-six patients (chronological mean age, $8.7 \pm 1.4$ years; mean treatment duration, 10.3 \pm 1.3 months) with functional and mild skeletal class III malocclusion were selected and treated with FR-3 appliances. Lateral cephalogram was taken pre- and post-treatment, and the data was analyzed by paired-samples t test with SPSS22.0 software package. Differences were considered statistically significant at $\mathrm{P}<0.05$. The results demonstrated that the FR-3 appliance produced a statistically significant decrease in L1-NB, L1-MP, U1-L1 ( P<0.01) and an increase greatly in ANB, MP-FH, Y axis, ANS$\mathrm{Me}$, ANS-Me/N-Me and overjet $(\mathrm{P}<0.01)$. SNA, SNB were increased significantly $(\mathrm{P}<0.05)$. Meanwhile, N'-Sn-Pog', ULSn-SN, LLSiSN increased, S-N'-Si, LL-EP decreased with significant difference ( $<<0.01)$. S-N'-Sn, Cm-Sn-UL, UL-EP, Sn-Mes and Ns-Mes increased with significant difference $(\mathrm{P}<0.05)$. Therefore it was concluded that after FR-3 treatment, the position of mandible may rotate clockwise backwards and downwards, with the labioversion of upper incisors and linguoversion of lower incisors. Although point A moved mesially, the length and position of the maxilla did not change significantly. With the protrusion of upper lip and the retrusion of lower lip, the relationship among nose, upper lip, lower lip and chin become harmonious, the profile of soft tissue is more coordinated and attractive.

KEY WORDS: Class III malocclusion; Frankel functional regulator III; Cephalometric analysis; Morphological changes.

\section{INTRODUCTION}

Facial aesthetics place more emphasis on interpersonal communication, and attractive faces are perceived as being more optimistic, outgoing, intelligent and confident. However, Class III malocclusion in mixed dentition is a common clinical deformity, characterized by mild to moderate concave profile, which may seriously impact children's jaw development, facial appearance and mental health (Xu et al., 2018). Its incidence varies from 5$15 \%$ in our populations (Woon \& Thiruvenkatachari, 2017), and the problem is more significant in countries such as Turkey, Japan and Korea, the highest prevalence of $15.8 \%$ has been observed in Southeast Asian populations in previous studies (Ngan \& Moon, 2015). Because of its hereditary, repetitive, unpredictable growth and development characteristics, Class III malocclusion is one of the most complicated cases of all dentofacial abnormalities in orthodontic clinical treatment. The establishment and development of Class III malocclusion can occur from the early stages, and the early functional alterations can permanently affect the growth of craniofacial structures (Pangrazio-Kulbersh et al., 2018). Children with a Class III malocclusion may have an underdeveloped maxilla, an overdeveloped mandible, or a combination of both. These skeletal problems may be combined with dental abnormalities, such as a protrusive maxillary and retrusive mandibular dentition (Al-Mozany et al., 2017). Therefore, the timing and treatment principles have always been the focus of research. Compared with severe skeletal Class malocclusion in preadolescents, which are usually treated by facemasks or rapid palatal expansion appliances (Shi et

\footnotetext{
${ }^{1}$ Department of Orthodontics, School of Dentistry, Shanxi Medical University, Taiyuan, China.

${ }^{2}$ Shanxi Province Key Laboratory of Oral Diseases Prevention and New Materials, Taiyuan, China.

${ }^{3}$ Department of Orthodontics, School of Dentistry, Kyungpook National University, Daegu, Korea.

FUNDING: Supported by Cultivate Scientific Research Excellence Programs of Higher Education Institutions in Shanxi, No.2019KJ024

Shanxi Province returned overseas students research funding projects, No.2019-076

Key projects of science and technology in Shanxi Province, No. 201803D31065
} 
al., 2020), the FR-3 appliance can be the ideal choice in functional and mild skeletal Class III malocclusion because of its simple wearing, basically no pain and less effect by the replacement of teeth.

Nowadays there are different views on the reconstruction of mandible and maxilla of FR-3 appliance, especially few evaluation studies on the important results of facial soft tissue changes. Therefore, the aim of this study was to evaluate the hard and soft tissue profile changes via cephalometric analysis following the treatment for functional and mild skeletal Class III malocclusion in mixed dentition by means of the FR-3 appliance, and to reveal the mechanism and effectiveness of treatment with FR-3 appliances.

\section{MATERIAL AND METHOD}

Material selection. Twenty-six prepubertal patients (12 males and 14 females) with functional and mild skeletal Class III malocclusion in the mixed dentition were selected from department of orthodontics, Shanxi Medical University stomatological hospital in 2017-2019. Mean chronological ages of the subjects were $8.7 \pm 1.4$ years, ranging from 6 to 11 years old, and the average treatment duration is $10.3 \pm 1.3$ months. Inclusion criteria: 1) functional and mild skeletal class III malocclusion in mixed dentition, mandible can retreat to the opposite edge of anterior teeth; 2) mesial molars relationship; 3) anterior overjet $\leq 0 \mathrm{~mm}$; 4) typical Class III malocclusion concave profile; 5) good cooperation during the treatment period. Exclusion criteria: 1) cleft lip and palate or other systemic disease; 2) history of trauma, maxillofacial surgery or orthodontic treatment.

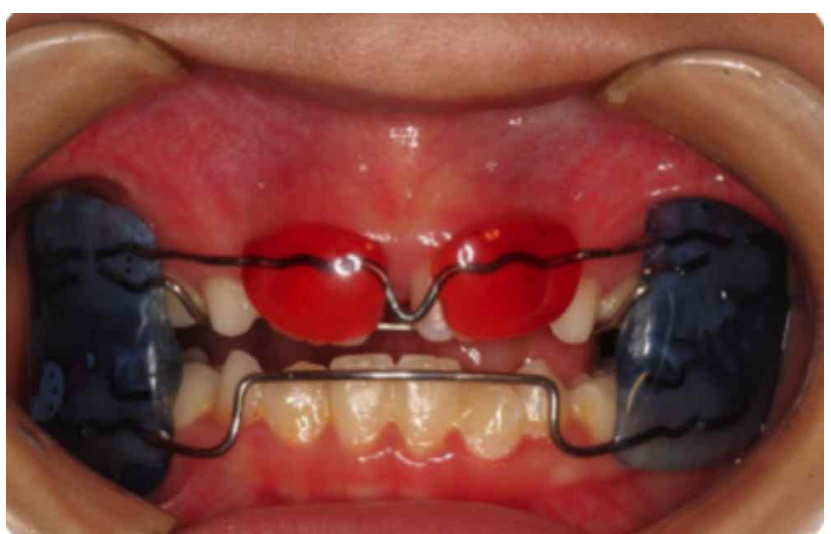

Fig. 1. FR-3 appliance.

Clinical application of FR-3 appliance. The FR-3 appliance used in this study is shown in Figure 1. The patient will have a follow-up visit one week after first wearing the appliance and once a month later. All patients should wear appliances no less than 14-16 hours per day until the molars reach a neutral relationship, the anterior crossbite are released, and the normal overbite coverage is restored.

Measuring method. Lateral cephalograms were obtained from all patients with FR-3 appliance at the beginning and after treatment. All films were taken in a standard position using the same equipment under the same conditions by one operator, and the measurement were digitized and calculated with the "Uceph" (Orthodontic Software, Sichuan China) analysis program. All fixed points were completed by the same person. Each set of points was determined twice, with a time interval of 2 weeks.

Measurement index of hard tissue. 1) SNA: sella-nasionpoint $\mathrm{A}$ angle, representing the anterior-posterior position of the maxilla relative to the skull; 2) SNB: sella-nasionpoint $\mathrm{B}$ angle, representing the anterior-posterior position of the mandible relative to the skull; 3) ANB: point A-nasionpoint $B$ angle, representing the relative position of the maxilla and mandible to the skull; 4) MP-FH: representing the steepness of the mandible; 5) $\mathrm{Y}$ axis: the line through the point $\mathrm{S}$ and $\mathrm{Gn}$, representing the degree of protrusion of chin; 6) U1-NA, U1-SN: representing the inclination of the maxillary incisor; 7) L1-NB, L1-MP: representing the inclination of the mandibular incisor; 8) ANS-Ptm: representing the length of maxilla; 9) S-Ptm: representing the anterior-posterior position of the maxillary; 10) Pog-Go: representing the length of mandible; 11) ANS-Me: representing the lower face height; 12) ANS-Me/N-Me: representing the lower face height to total face height ratio; 13) overjet: distance from the upper incisor' edge to the labial surface of the lower anterior teeth; 14) overbite: distance between upper and lower incisor edge (Fig. 2).

Measurement index of soft tissue. 1) S-N'-Sn: upper lip base angle, representing the convexity of maxilla; 2) S-N'$\mathrm{Si}$ : lower lip base angle, representing the convexity of mandible; 3) N'-Sn-Pog': representing facial profile of soft tissue profile in maxillofacial region; 4) $\mathrm{Cm}-\mathrm{Sn}-\mathrm{UL}$ : nasolabial angle, representing the protrusion of upper lip and upper anterior teeth; 5) LL-Si-Pog': representing the protrusion of lower lip and lower anterior teeth; 6) ULSnSN: representing the upper lip protrusion; 7) LLSi-SN: representing the lower lip protrusion; 8) UL-E plane: distance from UL point to the line consisting of the Prn and Pog' point, representing the upper lip protrusion; 9) LL-E: distance from LL point to the line consisting of the Prn and Pog' point, representing the lower lip protrusion; 10) N'-Sn: soft tissue upper face height; 11) Sn-Mes: soft tissue lower face height; 12) N'-Mes: soft tissue total face height (Fig. 3). 


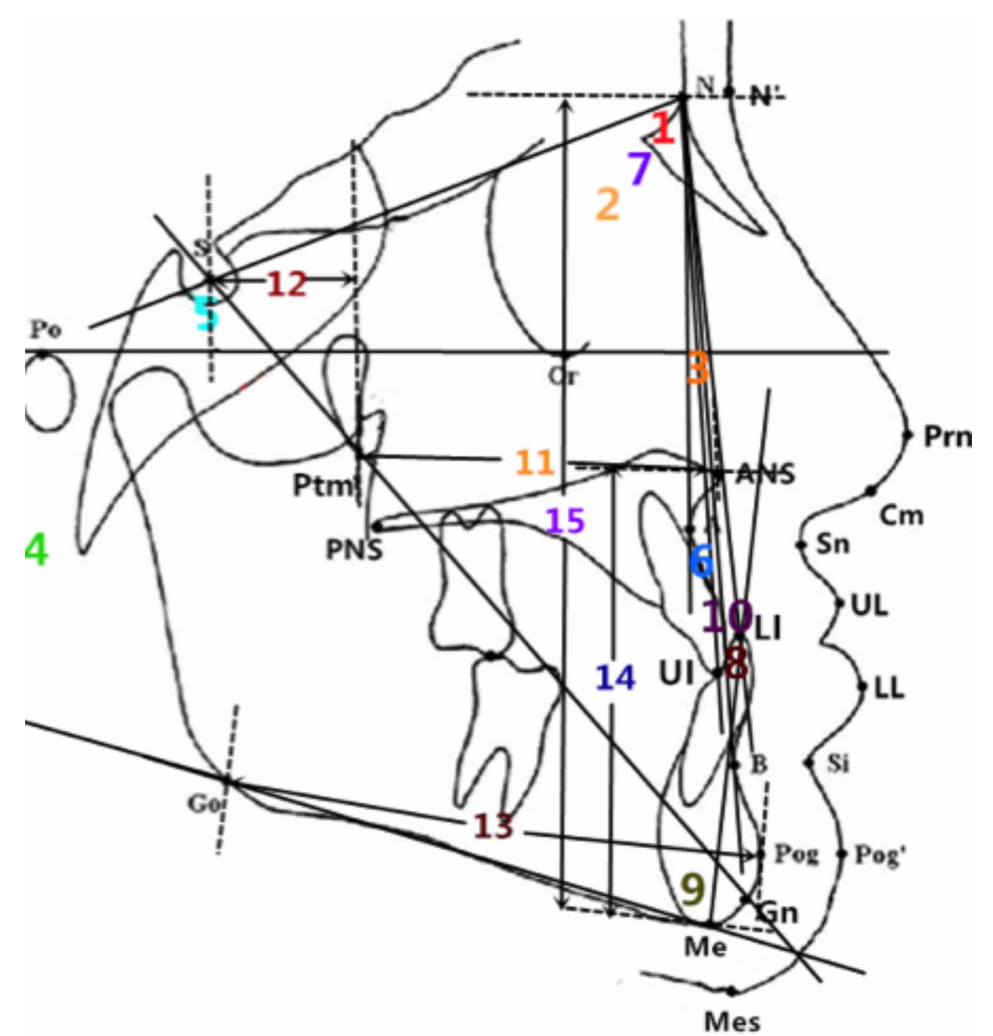

the soft tissue profile analysis are presented in Table II. N'-Sn-Pog', ULSn-SN, LLSi-SN increased, $\mathrm{S}-\mathrm{N}$ '-Si, LL-E plane decreased with significant difference $(\mathrm{P}<0.01)$. S-N'-Sn, CmSn-UL, UL-E plane, Sn-Mes, N'-Mes increased with significant difference $(\mathrm{P}<0.05)$. The increase of N'-Sn was not statistically significant.

Typical cases. A 8-year-old girl presented with a functional anterior crossbite, who had a significant concave profile in mixed dentition. About 4 months after wearing the FR-3 appliance, the anterior crossbite reversed, and the appliance was continued to be worn. After 11 months, normal occlusion of anterior teeth was established, and the profile was greatly improved. The pre- and post-treatment intraoral and lateral profile photographs were shown in Figures 4 to 6 , and the lateral cephalometric analysis was superimposed for comparison, as shown in Figure 7.

Fig. 2. Measurement index of hard tissue in the study: 1) SNA; 2) SNB; 3 ) ANB; 4) MP-FH; 5) Y axis; 6) U1-NA; 7) U1-SN; 8) L1-NB; 9) L1-MP; 10) U1-L1; 11) ANS-Ptm; 12) S-Ptm; 13) Pog-Go; 14) ANS-Me; 15) N-Me.

Statistical Analysis. Establish database with excel version 2016. The data obtained from the cephalograms were statistically analyzed by paired-samples $t$ test with SPSS22.0 software package. P-values $<0.05$ were considered statistically significant.

\section{RESULTS}

All patients showed a good level of compliance. At the end of the treatment, the anterior crossbite was relieved and the profile improved significantly. The statistically significant results of the hard tissue analysis are presented in Table I. Cephalometric analysis revealed a significant increase in ANB, MP-FH, $\mathrm{Y}$ axis, U1-NA, U1-SN, ANS-Me, ANS-Me/N$\mathrm{Me}$, Overjet $(\mathrm{P}<0.01)$, and a decrease in SNB, LI-NB, LI-MP. No significant differences were noted in ANS-Ptm, S-Ptm, Pog-Go and overbite $(P>0.05)$. The statistically significant results of

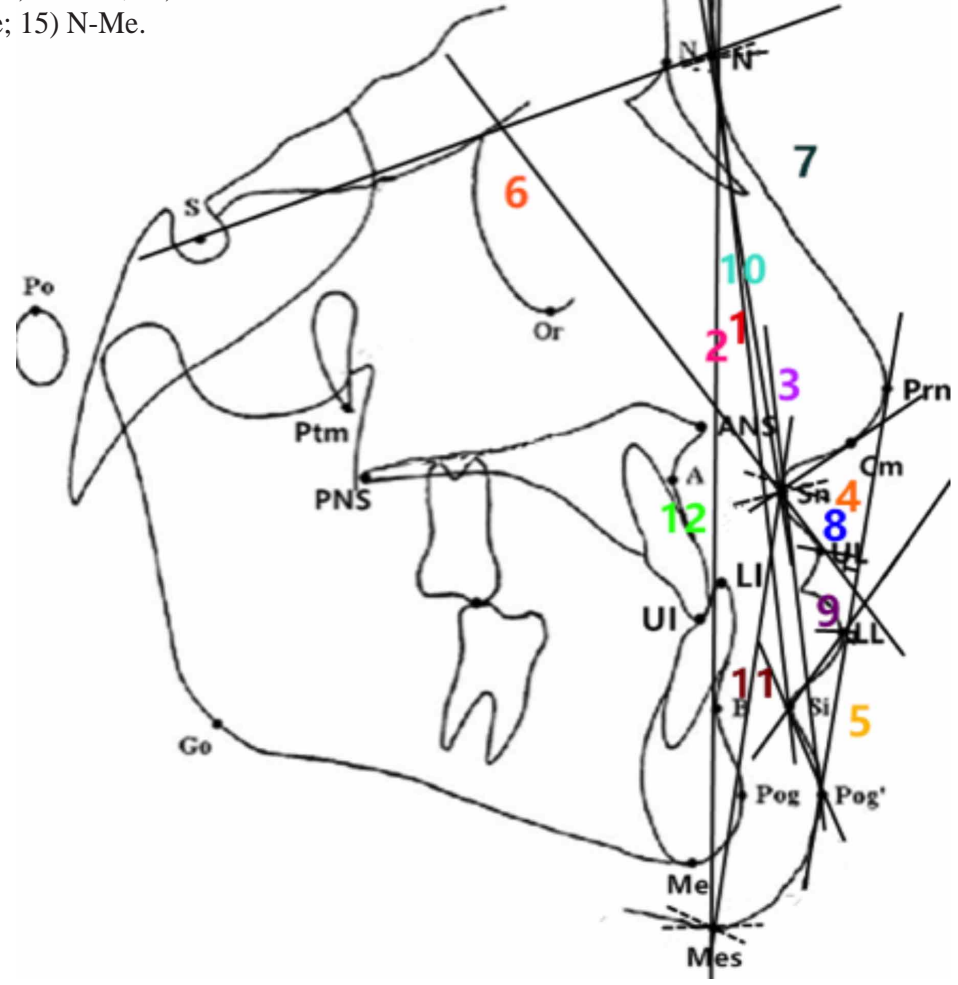

Fig. 3. Measurement index of soft tissue in the study: 1) S-N'-Sn; 2) S-N'Si; 3$)$ N'-Sn-Pog'; 4) Cm-Sn-UL; 5) LL-Si-Pog'; 6) ULSn-SN; 7) LLSiSN; 8) UL-E plane; 9) LL-E plane; 10) N'-Sn; 11) Sn-Mes; 12) N'-Mes. 

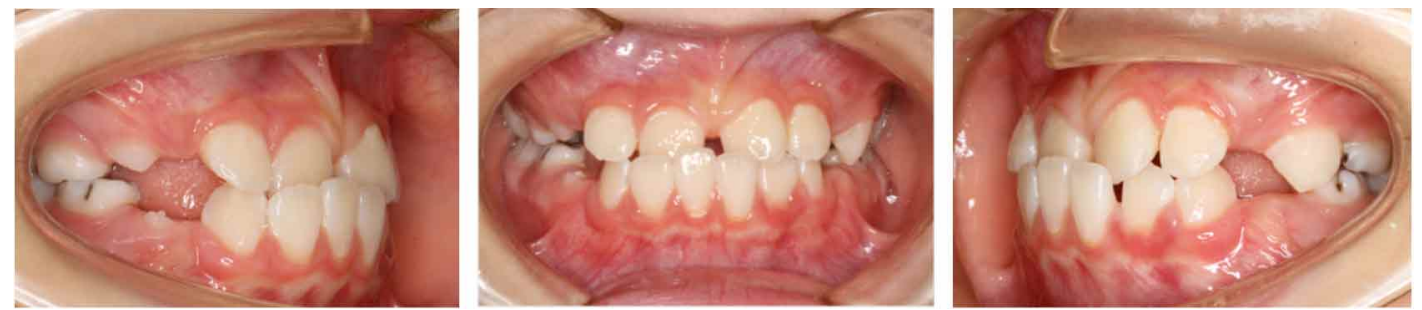

Fig. 4. Pre-treatment intraoral photographs.
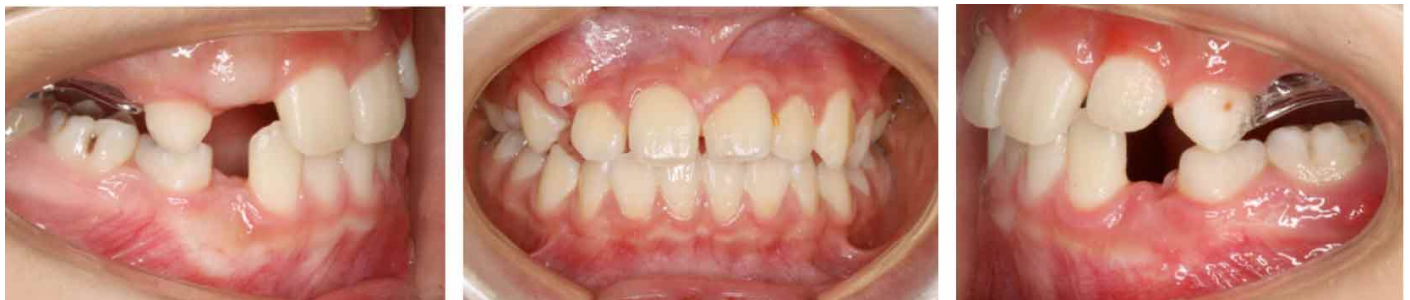

Fig. 5. Post-treatment intraoral photographs.
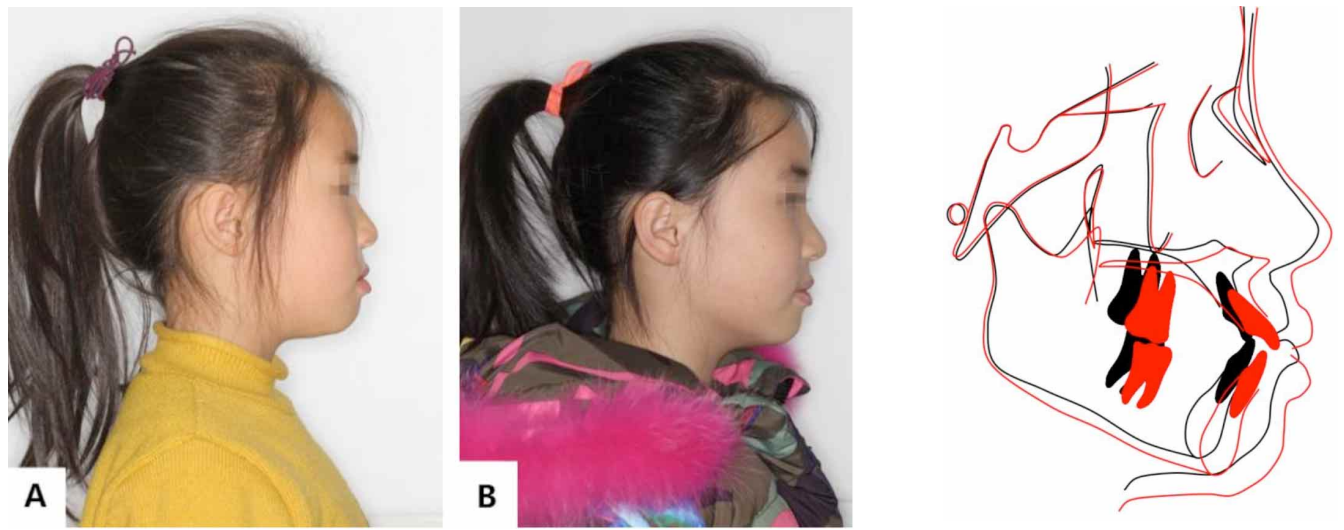

Fig. 7. Pre- (Black) and post- (Red) treatment cephalograms superimposed tracings.

Fig. 6. Pre- (A) and post- (B) treatment lateral profile photographs.

Table I. Descriptive of the pre- (T1) and post-treatment (T2) measurements of hard tissue changes.

\begin{tabular}{|c|c|c|c|c|c|c|c|}
\hline \multirow{2}{*}{ Parameters } & \multicolumn{2}{|c|}{ T1 } & \multicolumn{2}{|c|}{$\mathrm{T} 2$} & \multicolumn{2}{|c|}{$\mathrm{T} 2-\mathrm{T} 1$} & \multirow{2}{*}{$\mathrm{P}$ value } \\
\hline & Mean & SD & Mean & SD & Mean & SD & \\
\hline \multicolumn{8}{|l|}{ Angular $\left(^{\circ}\right)$} \\
\hline SNA & 79.7 & 4.4 & 80.1 & 4.7 & 0.5 & 0.8 & $<0.05$ \\
\hline SNB & 79.6 & 3.9 & 79.3 & 3.3 & -0.3 & 0.7 & $<0.05$ \\
\hline ANB & 0.4 & 1.4 & 1.2 & 0.9 & 0.9 & 0.6 & $<0.01$ \\
\hline MP-FH & 32.5 & 4.5 & 32.9 & 4.1 & 0.4 & 0.7 & $<0.01$ \\
\hline $\mathrm{Y}$ axis & 67.1 & 3.3 & 69.6 & 4.4 & 2.4 & 2.4 & $<0.01$ \\
\hline U1-NA & 26.9 & 9.1 & 28.5 & 7.5 & 1.6 & 2.2 & $<0.01$ \\
\hline U 1-SN & 100.6 & 6.0 & 104.2 & 4.8 & 3.6 & 4.2 & $<0.01$ \\
\hline L1-NB & 30.2 & 2.7 & 27.0 & 5.3 & -3.2 & 2.8 & $<0.01$ \\
\hline L1-MP & 88.4 & 5.7 & 85.7 & 6.4 & -2.7 & 4.3 & $<0.01$ \\
\hline U 1-L1 & 134.8 & 10.0 & 125.6 & 5.8 & -9.2 & 8.4 & $<0.01$ \\
\hline \multicolumn{8}{|l|}{ Length (mm) } \\
\hline ANS-Ptm & 39.2 & 2.5 & 39.5 & 1.7 & 0.3 & 2.0 & $>0.05$ \\
\hline S-Ptm & 18.2 & 1.5 & 18.5 & 2.2 & 0.3 & 3.3 & $>0.05$ \\
\hline Pog-Go & 62.7 & 4.7 & 63.4 & 3.2 & 0.7 & 2.7 & $>0.05$ \\
\hline ANS-Me & 53.2 & 2.5 & 55.7 & 3.3 & 2.5 & 1.5 & $<0.01$ \\
\hline ANS-Me/N-Me & 57.3 & 1.6 & 58.6 & 1.4 & 1.3 & 1.4 & $<0.01$ \\
\hline \multicolumn{8}{|l|}{ Others (mm) } \\
\hline Overjet & -2.2 & 1.4 & 1.7 & 0.9 & 3.9 & 2.6 & $<0.01$ \\
\hline Overbite & 1.7 & 1.5 & 1.4 & 1.1 & -0.3 & 1.6 & $>0.05$ \\
\hline
\end{tabular}


Table II. Descriptive statistics of pre- (T1) and post-treatment (T2) measurements of soft tissue profile changes.

\begin{tabular}{|c|c|c|c|c|c|c|c|}
\hline \multirow{2}{*}{ Paramete rs } & \multicolumn{2}{|c|}{$\mathrm{T} 1$} & \multicolumn{2}{|c|}{$\mathrm{T} 2$} & \multicolumn{2}{|c|}{$\mathrm{T} 2-\mathrm{T} 1$} & \multirow{2}{*}{$P$ value } \\
\hline & Mean & SD & Mean & SD & Mean & SD & \\
\hline \multicolumn{8}{|l|}{ Angular $\left(^{\circ}\right)$} \\
\hline S-N'-Sn & 87.6 & 2.1 & 88.8 & 3.1 & 1.2 & 1.6 & $<0.05$ \\
\hline S-N'-Si & 89.5 & 3.3 & 86.9 & 2.8 & -2.6 & 2.0 & $<0.01$ \\
\hline N'-Sn-Pog' & 4.5 & 1.9 & 11.4 & 2.0 & 6.9 & 1.3 & $<0.01$ \\
\hline Cm-Sn-UL & 98.4 & 14.6 & 103.1 & 13.9 & 4.7 & 5.3 & $<0.05$ \\
\hline LL-Si-Pog' & 68.6 & 4.4 & 72.8 & 5.3 & 4.2 & 8.7 & $>0.05$ \\
\hline ULSn-SN & 102.5 & 3.4 & 105.5 & 1.3 & 3.0 & 4.0 & $<0.01$ \\
\hline LLSi-SN & 43.5 & 3.0 & 49.4 & 3.0 & 5.9 & 2.2 & $<0.01$ \\
\hline \multicolumn{8}{|l|}{ Length(mm) } \\
\hline UL-E plane & -0.9 & 2.0 & 1.3 & 1.9 & 2.2 & 2.9 & $<0.05$ \\
\hline LL-E plane & 3.5 & 1.8 & 2.0 & 1.2 & -1.5 & 0.7 & $<0.01$ \\
\hline $\mathrm{N}^{\prime}-\mathrm{Sn}$ & 51.6 & 3.4 & 52.3 & 2.6 & 0.8 & 1.6 & $>0.05$ \\
\hline Sn-Mes & 58.7 & 2.9 & 60.8 & 3.3 & 2.1 & 2.9 & $<0.05$ \\
\hline N'-Mes & 109.3 & 5.7 & 112.1 & 4.8 & 2.9 & 4.0 & $<0.05$ \\
\hline
\end{tabular}

\section{DISCUSSION}

Class III malocclusion in mixed dentition is one of the most challenging situations for orthodontists, mainly for the uncertainly of stable long-term results owing to the interaction of both genetic inheritance and environmental factors (D'Apuzzo et al., 2019). Due to the increasing trend of growth and development, it has been widely reported that active intervene of Class III malocclusion in the early stage can improve the appearance of the patients, reduce the degree of deformity and promote the coordinated development of soft and hard tissues (Almeida et al., 2015; Tseng et al., 2016). Although there are some defects in FR-3 appliance, such as discomfort in large size, it is still an important means in the orthodontic treatment of Class III malocclusion, especially in mixed dentition, because the mechanism of FR3 appliance is that the lip pads and buccal shields can relieve the development of the upper arch of the periorbital muscle, and to stretch the periosteum of the vestibular mucosa to stimulate bone hyperplasia and stimulate the growth of alveolar and basal bone (Ngan et al., 1996). Whether FR3 appliance can reconstruction bone and alveolar bone remains to be debated, nowadays there is almost no dispute that the FR-3 appliance may rotate the mandible in a backward and downward direction (Baik et al., 2004; Kalavritinos et al., 2005), but there is some controversy about the skeletal effects in the maxilla, although the introduction of this appliance to clinical orthodontics dates back to the 1970s. Some scholars have observed substantial effects due to FR-3 appliance's treatment on the maxillary basal bone (Levin et al., 2008). On the other hand, some scholars claimed that the correction of a Class III malocclusion is produced mainly by the clockwise rotation of the mandibular and/or the alterations in upper and lower incisors inclinations (Kilic et al., 2011; Yang et al., 2014). After the treatment of FR-3 appliance in our study, MP-FH, ANS-Me and ANS$\mathrm{Me} / \mathrm{N}-\mathrm{Me}$ showed a statistically significant increase, demonstrating that the FR-3 appliance can produce the mandible to rotate backward and downward, which is beneficial to improve the general class III concave facial profile, but it should be used with caution in the high-angle patient to prevent the occurrence of open occlusion (Baik et al.; Kalavritinos et al.). Although the mandibular posterior rotation was more obvious after treatment, the mandibular length was increased $(\mathrm{P}>0.05)$, indicating that the FR-3 was no obvious limiting effect for the growth of the mandible. No significant differences were noted in ANS-Ptm and SPtm $(\mathrm{P}>0.05)$, indicating that even though the point A moved mesially, the length and position of the maxilla did not change significantly. In this study a statistically significant increase was noted in the overjet, U1-NA, U1-SN, and a significant decrease in LI-NB, L1-MP $(\mathrm{P}<0.01)$, it can be concluded that the changes following treatment with the FR3 appliance are primarily in dentoalveolar (Kilic et al., 2010). In short, the hard tissue treatment effects of the FR-3 appliance in this study can be considered to both skeletal and dentoalveolar changes. The skeletal effects were mainly obtained by the backward and downward rotation of the mandible with little forward growth stimulation on the maxilla, whereas the dentoalveolar effects were mostly due to the labial inclination of the maxillary incisors and linguoversion of the mandibular incisors (Baik et al.; Kilic et al., 2010). Although the point A moved mesially, the length and position of the maxilla did not change significantly. 
Most scholars think that orthodontists should pay more attention to soft tissue profile than to hard tissue merely, considering that patients and parents are often eager to improve their profile aesthetic. Scholars claimed that the difference of soft tissue profile is mainly concentrated in lower $1 / 3$ of the face, and the harmony of the relationship between nose, lip and chin can improve profile aesthetics (Ghorbanyjavadpour \& Rakhshan, 2019). After treatment of FR-3 appliance in our study, the S-N'-Sn, N'-Sn-Pog', ULSn-SN, LLSi-SN increased, S-N'-Si decreased with significant difference, indicating that the base of upper lip forward and upper lip and chin moved back obviously, patient's profile became protrudent after treatment, and the type concave profile has improved, which considering the following reasons: 1 . the mesial movement of point A results in the corresponding soft tissue point Sn moves mesially; 2. with the clockwise rotation of mandible, the soft tissue point Pog' moves forward and backward, which eventually increases the N'-Sn-Pog' angle. The most profound changes of soft tissue profile were the upper and lower lips in the sagittal direction. Cephalometric evaluation revealed a significant decrease in LL-EP distance and an increase greatly in UL-EP distance, suggesting that the patient's upper lip moves in the mesial and the lower lip appears in the distal movement after treatment, which plays an active role in the improvement of the type concave profile (Kilic et al., 2010). The cause of the changes in lip protrusion may be due to the labial inclination of the upper anterior teeth, the lingual inclination of the lower anterior teeth, and the change of the mandibular position by FR-3 appliance. In addition, special attention should be paid to the training of lip sealing in the treatment process of using FR-3 appliance, otherwise it will affect the development of the whole maxillofacial region. In conclusion, after treatment by FR-3 appliance, the relationship among nose, upper lip, lower lip and chin become harmonious, the profile of soft tissue is more coordinated and attractive, which improve the children's profile and promotes the physical and mental health.

According to the results of this study, it can be concluded that FR-3 appliance can rotate the mandible clockwise backwards and downwards, with the labioversion of upper incisors and linguoversion of lower incisors. Although the point A moved mesially, the length and position of the maxilla did not change significantly. Meanwhile, with the protrusion of upper lip and the retrusion of lower lip, the relationship among nose, upper lip, lower lip and chin become harmonious, the profile of soft tissue is more coordinated and attractive. These results confirm a more favorable functional and esthetic maxillary and mandibular position following treatment with the FR3 appliance.
JI, L. L.; SUN, D. X.; SHI, L. B.; KYUNG, H. M.; BING, L. \& WU, X.P. Cambios morfológicos del regulador funcional Frankel III en dentición mixta con maloclusión Clase III. Int. J. Morphol., 38(4):1053-1059, 2020.

RESUMEN: El objetivo de este estudio fue evaluar los cambios en el perfil de los tejidos duros y blandos después del tratamiento de la maloclusión funcional y leve de la clase III esquelética en la dentición mixta mediante el aparato regulador funcional Frankel (FR-3), y revelar el mecanismo y efectividad del tratamiento con el aparato FR-3. Veintiseis pacientes (edad media 8,7 $\pm 1,4$ años; duración media del tratamiento, 10,3 $\pm 1,3$ meses) con maloclusión funcional y leve de clase esquelética III fueron seleccionados y tratados con aparatos FR-3. El cefalograma lateral se tomó antes y después del tratamiento, y los datos se analizaron mediante la prueba t de muestras con el software SPSS22.0. Las diferencias se consideraron estadísticamente significativas a $\mathrm{P}$ $<0,05$. Los resultados demostraron que el dispositivo FR-3 produjo una disminución estadísticamente significativa en L1-NB, L1MP, U1-L1 (P <0,01) y un gran aumento en ANB, MP-FH, eje Y, ANS-Me, ANS -Me / N-Me y overjet $(\mathrm{P}<0,01)$. SNA, SNB se incrementaron significativamente $(\mathrm{P}<0,05)$. Mientras tanto, N'Sn-Pog', ULSn-SN, LLSi-SN aumentaron, S-N'-Si, LL-EP disminuyeron con una diferencia significativa $(\mathrm{P}<0,01)$. S-N'-Sn, Cm-Sn-UL, UL-EP, Sn-Mes y Ns-Mes aumentaron con una diferencia significativa $(\mathrm{P}<0,05)$. Por lo tanto, se concluyó que después del tratamiento con FR-3, la posición de la mandíbula puede girar en sentido reloj hacia atrás y hacia abajo, con labioversión de los incisivos superiores y linguoversión de los incisivos inferiores. Aunque el punto A se movió mesialmente, la longitud y la posición del maxilar no cambiaron significativamente. Con la protuberancia del labio superior y la retrusión del labio inferior, la relación entre la nariz, el labio superior, el labio inferior y el mentón se armoniza, el perfil del tejido blando es más coordinado y atractivo.

PALABRAS CLAVE: Clase III maloclusión; Regulador funcional Frankel III; Análisis cefalométrico; Cambios morfológicos.

\section{REFERENCES}

Al-Mozany, S. A.; Dalci, O.; Almuzian, M.; Gonzalez, C.; Tarraf, N. E. \& Ali Darendeliler, M. A novel method for treatment of Class III malocclusion in growing patients. Prog. Orthod., 18(1):40, 2017.

Almeida, R. R.; Alessio, L. E.; Almeida-Pedrin, R. R.; Almeida, M. R.; Pinzan, A. \& Vieira, L. S. Management of the Class III malocclusion treated with maxillary expansion, facemask therapy and corrective orthodontic. A 15-year follow-up. J. Appl. Oral Sci., 23(1):101-9, 2015.

Baik, H. S.; Jee, S. H.; Lee, K. J. \& Oh, T. K. Treatment effects of Fränkel functional regulator III in children with class III malocclusions. Am. J. Orthod. Dentofacial Orthop., 125(3):294-301, 2004.

D’Apuzzo, F.; Grassia, V.; Quinzi, V.; Vitale, M.; Marzo, G. \& Perillo, L. Paediatric orthodontics. Part 4: SEC III protocol in Class III malocclusion. Eur. J. Paediatr. Dent., 20(4):330-4, 2019.

Ghorbanyjavadpour, F. \& Rakhshan, V. Factors associated with the beauty of soft-tissue profile. Am. J. Orthod. Dentofacial Orthop., 155(6):83243, 2019. 
Kalavritinos, M.; Papadopoulos, M. A. \& Nasiopoulos, A. Dental arch and cephalometric changes following treatment for class III malocclusion by means of the function regulator (FR-3) appliance. J. Orofac. Orthop., 66(2):135-47, 2005.

Kilic, N.; Celikoglu, M. \& Oktay, H. Effects of the functional regulator III on transversal changes: a postero-anterior cephalometric and model study. Eur. J. Orthod., 33(6):727-31, 2011.

Kilic, N.; Celikoglu, M. \& Oktay, H. Effects of the functional regulator III on profile changes in subjects with maxillary deficiency. Eur. J. Orthod., 32(6):729-34, 2010.

Levin, A. S.; McNamara, J. A. Jr.; Franchi, L.; Baccetti, T. \& Fränkel, C. Short-term and long-term treatment outcomes with the FR-3 appliance of Fränkel. Am. J. Orthod. Dentofacial Orthop., 134(4):513-24, 2008.

Ngan, P. \& Moon, W. Evolution of Class III treatment in orthodontics. Am. J. Orthod. Dentofacial Orthop., 148(1):22-36, 2015.

Ngan, P.; Hägg, U.; Yiu, C.; Merwin, D. \& Wei, S. H. Soft tissue and dentoskeletal profile changes associated with maxillary expansion and protraction headgear treatment. Am. J. Orthod. Dentofacial Orthop., 109(1):38-49, 1996.

Pangrazio-Kulbersh, V.; Kang, H. K.; Dhawan, A.; Al-Qawasmi, R. \& Pacheco, R. R. Comparison of early treatment outcomes rendered in three different types of malocclusions. Angle Orthod., 88(3):253-8, 2018.

Shi, H.; Ge, H. S.; Chen, L. Y. \& Li, Z. H. Meta-analysis of the efficacy of bone anchorage and maxillary facemask protraction devices in treating skeletal class? malocclusion in adolescents. Hиа Xi Kои Qiang Yi Хие Za Zhi, 38(1):69-74, 2020.

Tseng, L. L.; Chang, C. H. \& Roberts, W. E. Diagnosis and conservative treatment of skeletal Class III malocclusion with anterior crossbite and asymmetric maxillary crowding. Am. J. Orthod. Dentofacial Orthop., 149(4):555-66, 2016.

Woon, S. C. \& Thiruvenkatachari, B. Early orthodontic treatment for Class III malocclusion: A systematic review and meta-analysis. Am. J. Orthod. Dentofacial Orthop., 151(1):28-52, 2017.

Xu, F. Y.; Kwon, T. G.; Kyung, H. M.; Bing. L. \& Wu, X. P. Morphological Changes of Skeletal Class III Malocclusion in Mixed Dentition with Protraction Combined Activities. Int. J. Morphol., 36(2):430-4, 2018.

Yang, X.; Li, C.; Bai, D.; Su, N.; Chen. T.; Xu, Y. \& Han, X. Treatment effectiveness of Fränkel function regulator on the Class III malocclusion: a systematic review and meta-analysis. Am. J. Orthod. Dentofacial Orthop., 146(2):143-54, 2014.

\author{
Corresponding author: \\ Xiu-Ping Wu \\ Stomatology Hospital \\ Shanxi Medical University \\ 63 Xinjian Road,Taiyuan 030001 \\ CHINA
}

Email: 77wxp@163.com

Received: 20-02-2020

Accepted: 28-03-2020 